\title{
Evaluating the Salinity Tolerance of Clonal-type Bermudagrass Cultivars and an Experimental Selection
}

\author{
Mingying Xiang, Justin Q. Moss ${ }^{1}$, Dennis L. Martin, Kemin Su, \\ and Bruce L. Dunn \\ Department of Horticulture and Landscape Architecture, Oklahoma State \\ University, Stillwater, OK 74078
}

\section{Yanqi Wu \\ Department of Plant and Soil Sciences, Oklahoma State University, Stillwater, OK 74078}

Additional index words. Cynodon dactylon, Cynodon transvaalensis, salts, turfgrass, hybrid bermudagrass

\begin{abstract}
Bermudagrass (Cynodon sp.) is a highly productive, warm-season, perennial grass that has been grown in the United States for turfgrass, forage, pasture, rangeland, and roadside use. At the same time, many bermudagrass production and reclamation sites across the United States are affected by soil salinity issues. Therefore, identifying bermudagrass with improved salinity tolerance is important for successfully producing bermudagrass and for reclaiming salt-affected sites with saline irrigated water. In this project, the relative salinity tolerance of seven clonal-type bermudagrass was determined, including industry standards and an Oklahoma State University (OSU) experimental line. The experiment was conducted under a controlled environment with six replications of each treatment. Seven bermudagrass entries were exposed to four salinity levels $\left(1.5,15,30\right.$, and $\left.45 \mathrm{dS} \cdot \mathrm{m}^{-1}\right)$ consecutively via subirrigation systems. The relative salinity tolerance among entries was determined by normalized difference vegetation index (NDVI), digital image analysis (DIA), leaf firing (LF), turf quality (TQ), shoot dry weight (SW), visual rating (VR), and dark green color index (DGCI). Results indicated that there were variable responses to salinity stress among the entries studied. As salinity levels of the irrigation water increased, all evaluation criterion decreased, except LF. All entries had acceptable TQ when exposed to $15 \mathrm{dS} \cdot \mathrm{m}^{-1}$. When exposed to $30 \mathrm{dS} \cdot \mathrm{m}^{-1}$, experimental entry OKC1302 had less LF than all other entries except 'Tifway', while 'Midlawn' showed more LF than all the entries. Leaf firing ranged from 1.0 to 2.7 at 45 $\mathrm{dS} \cdot \mathrm{m}^{-1}$, where 'Tifway' outperformed all other entries. At $45 \mathrm{dS} \cdot \mathrm{m}^{-1}$, the live green cover as measured using DIA ranged from $3.07 \%$ to $24.72 \%$. The parameters LF, TQ, NDVI, DGCI, SW, and DIA were all highly correlated with one another, indicating their usefulness as relative salinity tolerance measurements.
\end{abstract}

Bermudagrass is native to Africa, widely distributed, and commonly found in tropical and subtemperate areas (Taliaferro et al., 2004). It is important for forage, turfgrass use, and soil and water conservation. Hybrid bermudagrass [Cynodon dactylon (L.) Pers. $\times$ C. transvaalensis Burtt Davy] is widely used on golf courses, sport fields, and other highmaintenance turf areas in the United States (Hanna et al., 2013). Bermudagrass, a warmseason grass, lacks winterhardiness, which

Received for publication 23 Mar. 2016. Accepted for publication 5 July 2016

Approved for publication by the director of the Oklahoma Agricultural Experiment Station.

We thank Paul Raymer for advice and guidance on the salinity testing methods.

Funds to support this research were provided by the Oklahoma Agricultural Experiment Station and the National Institute of Food and Agriculture, U.S. Department of Agriculture, under award number 2010-51181-21064.

1'Corresponding author. E-mail: justin.moss@ okstate.edu. limits its use through the transition zone and into the northern part of the United States (Munshaw et al., 2004). Although scientists have developed and released bermudagrass cultivars with improved cold hardiness, the relative salinity tolerance of many of these releases has not been studied.

Salinity limits plant growth and production. Over 45 million hectares of irrigated land around the world have been affected by saline soil issues; 1.5 million hectares lack vitality due to soil salinity (Carillo et al., 2011; Munns and Tester, 2008). Since potable water scarcity is a growing problem as well, government-mandated water use restrictions are wide spread and this often requires the use of reclaimed water high in salinity (Marcum and Pessarakli, 2006). In response to these pressures, research has been done on turfgrass growth responses to different water-saving strategies, such as responses to saline water irrigation (Sevostianova et al., 2011). Finding ways to satisfy the need of water for human activities, while at the same time protecting the freshwater systems, now ranks among the 21 st century's most critical challenges.

Saline-tolerant plants can minimize inimical saline effects by generating a series of processes in the morphological, physiological, and biochemical levels (Jacoby, 1999; Uddin et al., 2011). Saline-tolerant bermudagrass cultivars could produce acceptable quality turf in areas where there is reclaimed water irrigation or soil saline issues (Uddin et al., 2011). Marcum (2008) ranked Cynodon $\mathrm{sp}$. as possessing excellent salinity tolerance turfgrass, but he also found that the salinity tolerance within the species is highly variable. Information on the relative salinity tolerance of bermudagrass cultivars and experimental selections will provide turfgrass breeders and managers with a greater selection pool.

In addition, it is important to determine the effectiveness of subjective and nondestructive evaluation parameters for plant salinity tolerance. NDVI has been used to evaluate TQ and drought response (Leinauer et al., 2014), but little work has used NDVI to evaluate salinity response in turf (Bell and Xiong, 2008). Recently, additional NDVI sensors and smartphone applications (App) have been marketed for turf evaluation, but little has been published regarding the effectiveness of these tools.

The objectives of this research were to 1) determine the relative salinity tolerance of clonal-type bermudagrass, including six industry standards and one OSU experimental line; 2) evaluate the response of the seven bermudagrass entries to salinity stress using the GreenSeeker ${ }^{\mathrm{TM}}$ handheld sensor (Trimble Navigation LTD, Sunnyvale, CA), the FieldScout ${ }^{\circledR}$ CM 1000 NDVI meter (N-Tech Industries Inc., Ukiah, CA), and the FieldScout $^{\circledR}$ GreenIndex + Turf App (Spectrum Technologies Inc., Aurora, IL) compared with the traditional visual TQ ratings and DIA.

\section{Materials and Methods}

Plant materials and growth conditions. Seven clonal-type bermudagrass entries, including 'Celebration', 'Latitude 36', 'Midlawn', 'NorthBridge', 'TifSport', 'Tifway', and experimental selection OKC1302, were evaluated based on their response to four salinity level treatments $(1.5,15,30$, and 45 $\mathrm{dS} \cdot \mathrm{m}^{-1}$ ) with six replications. 'Midlawn', 'Tifsport', and 'Tifway' were chosen as because of their use as industry standards and because they have been used in previous bermudagrass salinity experiments (Marcum and Murdoch, 1994; Marcum and Pessarakli, 2006). 'Celebration', 'Latitude 36', 'NorthBridge', and the experimental line OKC1302 were chosen because their relative salinity tolerance was unknown. In addition, 'Celebration' and 'Latitude 36' have been recognized as industry standards by the National Turfgrass Evaluation Program (National Turfgrass Evaluation Program, 2013).

We conducted the study at the OSU, Department of Horticulture and Landscape 
Architecture greenhouse facility located in Stillwater, OK, from July to Dec. 2014. Since turfgrass salinity tolerance greenhouse data have been shown to correlate well with turfgrass salinity tolerance field studies (Koch and Bonos, 2011), a controlled environment was used to decrease variability in salinity treatment and response. Air temperatures were maintained between 25 to $37^{\circ} \mathrm{C}$ during the day and between 21 to $30{ }^{\circ} \mathrm{C}$ at night. A 14-h photoperiod was maintained by supplemental high-pressure sodium light from 0700 to $2100 \mathrm{HR}$ to maximize photosynthetically active radiation on the experimental area. Maximum daily photosynthetic photon flux ranged from 700 to 1150 $\mu \mathrm{mol} \cdot \mathrm{m}^{-2} \cdot \mathrm{s}^{-1}$ during the experiment.

Bermudagrass entries were collected as $15.24 \mathrm{~cm} \times 15.24 \mathrm{~cm}$ sod plugs from a field nursery during July 2014 . The plugs were separated individually and washed to remove all soil particles. Roots were trimmed to $3 \mathrm{~cm}$ before transplanting 10 uniform sprigs to $11.14 \mathrm{~cm} \times 11.14 \mathrm{~cm}$ pots. The grasses were established in sand, which met the U.S. Golf Association (USGA) root zone specification for particle size (USGA Green Section Staff, 2004). The sand was mixed with gypsum at the rate of $3 \mathrm{~g} \cdot \mathrm{L}^{-1}$ of sand. The gypsum was mixed with the sand to provide $\mathrm{Ca}$, not due to a specific nutrient deficiency, but as a precautionary measure to prevent a possible nutrient deficiency as $\mathrm{Ca}$ has been shown to aid in uptake of nutrients in salinity-stressed plants (Guimaraes et al., 2012). During the establishment period before initiating salinity treatments, the grasses were fertilized three times weekly with a fertilizer solution containing $250 \mathrm{mg} \cdot \mathrm{L}^{-1} \mathrm{~N}$ using a solution of 20 $20-20 \quad \mathrm{~N}-\mathrm{P}_{2} \mathrm{O}_{5}-\mathrm{K}_{2} \mathrm{O} \quad(20 \mathrm{~N}-8.6 \mathrm{P}-16.6 \mathrm{~K})$ general purpose fertilizer (J.R Peters Inc., Allentown, PA).

After successful establishment of the grasses, pots were moved to two ebb and flow benches (one for the control treatment and one for the salinity treatments) for acclimation for 2 weeks. During the acclimation period, all pots were subirrigated daily on the ebb and flow benches from solution tanks (189 L) that were fitted with a water pump and timer. The greenhouse tap water source $\mathrm{pH}$ was 7.8 , electrical conductivity (EC) level was $0.5 \mathrm{dS} \cdot \mathrm{m}^{-1}$, and the sodium adsorption ratio (SAR) was 1.6. A nutrient solution containing Excel water-soluble fertilizer at $0.52 \mathrm{~g} \cdot \mathrm{L}^{-1}, 13-2-13+6 \mathrm{Ca}+3 \mathrm{Mg}$ plug special (Scotts-Sierra Horticultural Products Company, Marysville, $\mathrm{OH}$ ), and $\mathrm{MgSO}_{4}$ at $0.04 \mathrm{~g} \cdot \mathrm{L}^{-1}$ was added to all irrigation tanks for both the control and salinity treatment benches supplying daily a concentration of $68 \mathrm{mg} \cdot \mathrm{L}^{-1} \mathrm{~N}$. The baseline salinity level of the irrigation water after the addition of the nutrient solution was $1.5 \mathrm{dS} \cdot \mathrm{m}^{-1}$.

Mealy bugs (Pseudococcus sp.) and bermudagrass mites (Eriophes cynodoniensis Sayed) were detected on 'TifSport' during establishment. Therefore, all grasses were treated on 7-d intervals with imidacloprid (Merit 2F insecticide, Bayer Environmental Science, Research Triangle Park, NC) rotated with bifenthrin (Talstar Insecticide, FMC
Corporation Agricultural Products Group, Philadelphia, PA) and surfactant (Aduro, Winfield Solutions, LLC, St. Paul, MN) at labeled rates.

The turfgrass entries were established for 10 weeks and maintained at a 4-cm mowing height. Before initiating salinity treatment, pots were evaluated in several ways: visual TQ and LF measured by a human evaluator; NDVI by a GreenSeeker ${ }^{\mathrm{TM}}$ handheld sensor (GSNDVI) and a FieldScout ${ }^{\circledR}$ CM 1000 NDVI meter (FSNDVI) (Spectrum Technologies Inc.); DGCI and VR by the FieldScout ${ }^{\mathbb{B}}$ GreenIndex + Turf App; and DIA by a digital SLR camera and the SigmaScan Pro 5 software (Systat Software, Inc., San Jose, CA) (Karcher and Richardson, 2003; Richardson, 2001). To provide uniform starting conditions, shoots were clipped $1 \mathrm{~d}$ before initiation of salinity treatment (Marcum, 1999). The clippings were collected and measured for SW.

Salinity treatments. The control and salinity treatment tanks both contained irrigation water with the nutrient solution, as described in the section Plant Materials and Growth Conditions, and had a baseline EC of $1.5 \mathrm{dS} \cdot \mathrm{m}^{-1}$. On 25 Sept. 2014, data (TQ, LF, GSNDVI, FSNDVI, DGCI, VR, and DIA) were collected for all pots and then we gradually added an Instant Ocean Synthetic Sea Salt mix (Aquarium System, Mentor, $\mathrm{OH})$ to the salinity treatment tank to reach the appropriate salinity level. The salt concentration was increased by $5 \mathrm{dS} \cdot \mathrm{m}^{-1}$ daily in the treatment tank until $15 \mathrm{dS} \cdot \mathrm{m}^{-1}$ total salinity was reached (Marcum et al., 2005; Marcum and Pessarakli, 2006). The purpose of raising the EC by $5 \mathrm{dS} \cdot \mathrm{m}^{-1}$ daily was to reduce the occurrence of acute salinity stress to the plants. The treatment tank was held at $15 \mathrm{dS} \cdot \mathrm{m}^{-1}$ for 1 week, and then all data were collected for all the pots. We clipped the shoots, collected the clippings, and increased the salt dosage by $5 \mathrm{dS} \cdot \mathrm{m}^{-1}$ daily until it reached $30 \mathrm{dS} \cdot \mathrm{m}^{-1}$. Salinity was again held at $30 \mathrm{dS} \cdot \mathrm{m}^{-1}$ for 1 week, rated, and clipped. This cycle was repeated one more time to reach 45 $\mathrm{dS} \cdot \mathrm{m}^{-1}$. Data were collected exactly 1 week after salinity reached each scheduled level $\left(15,30\right.$, and $\left.45 \mathrm{dS} \cdot \mathrm{m}^{-1}\right)$. The total quantity of Instant Ocean Synthetic Sea Salt added for each EC level was $10.6 \mathrm{~g} \cdot \mathrm{L}^{-1}$ at $15 \mathrm{dS} \cdot \mathrm{m}^{-1}$, $21.1 \mathrm{~g} \cdot \mathrm{L}^{-1}$ at $30 \mathrm{dS} \cdot \mathrm{m}^{-1}$, and $31.7 \mathrm{~g} \cdot \mathrm{L}^{-1}$ at 45 $\mathrm{dS} \cdot \mathrm{m}^{-1}$. We applied $300 \mathrm{~mL}$ of the appropriate salinity treatment irrigation solution overhead every $5 \mathrm{~d}$ to regularly flush the pots and avoid an accumulation of salt in the growth media above the desired range due to evaporation.

Throughout the experiment, fertilizer levels were monitored daily by measuring the EC level of the control treatment tank with a portable EC meter (HI 9033; Hanna Instruments, Inc. Carrollton, TX). When the EC levels of the control treatment tanks dipped below $1 \mathrm{dS} \cdot \mathrm{m}^{-1}$, Excel fertilizer was added to all irrigation tanks (control and salinity treatments) at the rate of $0.27 \mathrm{~g} \cdot \mathrm{L}^{-1}$ of solution. Salt levels in the tanks were measured daily, adjusted when necessary, and solutions were changed every $10 \mathrm{~d}$ to avoid changes in nutrient ion concentrations.

\section{Parameters Evaluated}

Eight parameters were evaluated during the experiment to assess the performance of bermudagrass in each treatment.

\section{Turf Quality}

Turf quality ratings, which are not based on any single parameter alone, but on a combination of color, density, uniformity, texture, and disease or environmental stress, were rated on a scale of 1 to 9 based on the National Turfgrass Evaluation Program criteria, where $1=$ dead or dormant turf, $6=$ acceptable turf, and $9=$ outstanding or ideal turf (Morris, 2007).

\section{Leaf Firing}

Leaf firing, or visual browning of the leaves, was rated on a scale of 1 to 9 , where $1=$ complete leaf firing and $9=$ no wilting and no firing (Morris, 2007).

\section{Digital Image Analysis}

Digital photographs were taken using a Canon PowerShot G16 12.1 MP CMOS (Melville, NY). The camera was placed onto a lightbox constructed from a black-painted bucket that blocks unwanted light. The lightbox was placed over the individual pots and digital images were recorded. The digital image was analyzed via the Sigma Scan Pro 5 software to calculate percent green cover (Karcher and Richardson, 2003; Richardson, 2001). Hue was set to a threshold of 40 to 140 , and saturation 0 to 100 . Pictures were cropped to a $940 \times 940$ pixel image. Mean separation was calculated based on Fisher's protected least significant difference (LSD) after $\arcsin (\mathrm{DIA} / 100)$ transformation.

\section{GreenSeeker $^{\mathrm{TM}}$ Normalized Difference Vegetation Index}

Normalized difference vegetation index is a parameter correlated with leaf area index and with visual appearance of turfgrass (Crain et al., 2012; Leinauer et al., 2014), and the GSNDVI is calculated by the following equation:

$$
\mathrm{NDVI}=\frac{\mathrm{NIR}-\mathrm{VIS}}{\mathrm{NIR}+\mathrm{VIS}}
$$

where NIR $=$ spectral reflectance measurements acquired in the near-IR for a given pixel and VIS = spectral reflectance measurements acquired in the visible (red) range for a given pixel (Deering et al., 1975).

The GreenSeeker ${ }^{\mathrm{TM}}$ handheld sensor is a nondestructive, affordable, and simple to use NDVI sensor (Bell et al., 2009). The GSNDVI is calculated by the high-intensity light emitted by the sensor at 660 and $770 \mathrm{~nm}$ wavebands (Basyouni and Dunn, 2013). With values ranging from 0 to 1 , the larger the NDVI value, the healthier the plant. According to Basyouni (2014), the hooded GreenSeeker ${ }^{\mathrm{TM}}$ handheld sensor measures a smaller field of view, which is an applicable choice for the greenhouse study since it avoids 
background noise caused by the small canopy area. The black hood was attached to the bottom of the sensor and was matched with the diode viewing window. A black funnel was put on top of the greenhouse pot so that the bottom of the funnel and the top of the pot matched and further prevented background noise. The hooded GreenSeeker ${ }^{\mathrm{TM}}$ handheld sensor was placed $35.5 \mathrm{~cm}$ above the grass canopy with the parameter sampled three times and averaged.

\section{FieldScout ${ }^{\circledR}$ Normalized Difference Vegetation Index}

Similar to the GreenSeeker ${ }^{\mathrm{TM}}$ handheld sensor, the FieldScout ${ }^{\circledR}$ CM 1000 NDVI chlorophyll meter is another effective way to estimate plant health by instantly measuring red $(660 \mathrm{~nm})$ and near-IR $(840 \mathrm{~nm})$ spectral bands (Spectrum Technologies, Inc., 2013). The FSNDVI is calculated by the equation of

$$
\text { NDVI }=\frac{\% \text { Near Infrared }-\% \text { Red }}{\% \text { Near Infrared }+\% \text { Red }}
$$

The lens was held $49 \mathrm{~cm}$ above the grass canopy. All the samples were taken between 1200 and $1300 \mathrm{HR}$ under natural sun light with the same background, sampled three times, and averaged.

\section{FieldScout $^{\circledR}$ GreenIndex $^{-}$Turf App (DGCI and VR)}

The FieldScout ${ }^{\circledR}$ GreenIndex+ Turf App calculates the greenness of the turf via a smartphone, known as the DGCI, which provides a low-cost method for objectively measuring TQ and appearance, which is known as the VR. The turf DGCI was measured by converting the red, green, and blue (RGB) color scheme in the series of pixels into hue, saturation, and brightness (HSB). The DGCI was then calculated from the HSB values as follows:

$$
\begin{aligned}
\text { DGCI }= & \frac{1}{3}\left[\frac{\text { Hue }-60}{60}+(1-\text { Saturation })\right. \\
& +(1-\text { Brightness })]
\end{aligned}
$$

The app automatically calculated VR with the DGCI data (Spectrum Technologies, Inc., 2014). The green, yellow, and grey reference board from FieldScout ${ }^{\circledR}$ GreenIndex+ was used in each picture to improve the app's lighting and white balance consistency (Spectrum Technologies, Inc., 2014).

Data were collected with the FieldScout ${ }^{\circledR}$ GreenIndex+ Turf App at 1000 HR to minimize light fluctuations. An iPhone 5 (Apple, Cupertino, CA) containing the app was held $25 \mathrm{~cm}$ above the grass canopy; three pictures of the grass canopy were taken via the smartphone camera. The average of the DGCI and a default VR was calculated by the app in decimal form.

\section{Shoot Dry Weights}

Shoots were clipped at $4 \mathrm{~cm}$ every $5 \mathrm{~d}$. Clippings were collected in paper envelopes and dried at $80{ }^{\circ} \mathrm{C}$ for $48 \mathrm{~h}$, and SW was recorded. Relative shoot dry weight (SW/SW control) is a better indicator of plant vigor under salinity stress than absolute growth (Marcum and Pessarakli, 2006). The shoot growth response of each entry was determined by comparing the $\mathrm{SW}$ with the control following the formula proposed by Ashraf and Waheed (1990).

$$
\begin{aligned}
& \text { Relative growth }(\%) \\
& =\frac{\begin{array}{c}
\text { DW of salinized treatment } \\
\text { of a species }
\end{array}}{\mathrm{DW} \text { of the control treatment }} \quad \times 100 \\
& \text { of that species }
\end{aligned}
$$

For each cultivar, grass shoot growth response to salinity was determined by calculating the salinity level resulting in $25 \%$ (SW25) and 50\% shoot dry weight reduction (SW50), compared with the control (Marcum and Pessarakli, 2006).

Recovery after salinity stress. One week after the treatment level reached $45 \mathrm{dS} \cdot \mathrm{m}^{-1}$, the grasses were immediately watered to field capacity with a nutrient solution containing $2.6 \mathrm{~g} \cdot \mathrm{L}^{-1} \mathrm{~N} 13-2-13+6 \mathrm{Ca}+3 \mathrm{Mg}$ of a plug special fertilizer solution. The grasses under prior salinity stress were flushed overhead daily with a $300 \mathrm{~mL}$ solution for $7 \mathrm{~d}$ before switching to subirrigation for 8 weeks. Since a highly positive statistical correlation $\left(r^{2}>0.59\right)$ was found among the parameters, LF, TQ, FSNDVI, GSNDVI, DGCI, VR, DIA, and SW, a decision was made to focus only on the DIA for the recovery analysis. Data were collected on the $2 \mathrm{nd}$, 4 th, and 8 th week during the recovery period.

\section{Experimental Design and Statistical Analysis}

The experiment was conducted using a randomized complete block design, where salinity treatment was considered the main plot factor and cultivar/entry was considered the subplot factor. Data were analyzed with analysis of variance (ANOVA), and means separation was determined among entries using Fisher's Protected LSD at the 0.05 significance level using SAS 9.4 (SAS Institute Inc., Cary, NC). For the recovery evaluation, an ANOVA was conducted, and mean separation was performed using Tukey's procedure to analyze the DIA within the recovery cycles at the 0.05 significance level using SAS 9.4.

\section{Results}

Leaf firing. Leaf firing increased in all entries as salinity levels increased. No LF was found in any entry before initiating the salinity treatments (Table 1). All entries showed acceptable leaf firing at $15 \mathrm{dS} \cdot \mathrm{m}^{-1}$, ranging from 6.2 to 7.8. At this salinity level, the experimental entry OKC1302 had the least LF of all entries, while 'TifSport' had the most. When exposed to $30 \mathrm{dS} \cdot \mathrm{m}^{-1}$, experimental entry OKC1302 had less LF than all other entries except 'Tifway', whereas 'Midlawn' had the most. At 45 $\mathrm{dS} \cdot \mathrm{m}^{-1}$, LF ranged from 1.0 to 2.7 , where 'Tifway' outperformed all other entries. Overall, OKC1302 showed the least LF at $15 \mathrm{dS} \cdot \mathrm{m}^{-1}$ compared with the other cultivars, whereas Tifway displayed the least LF at 45 $\mathrm{dS} \cdot \mathrm{m}^{-1}$.

Turf quality. Turf quality decreased as

\begin{tabular}{|c|c|c|c|c|c|c|c|c|}
\hline \multirow[b]{3}{*}{ Entry } & \multicolumn{8}{|c|}{ Human evaluator (visual rating 1-9) } \\
\hline & \multicolumn{4}{|c|}{$\mathrm{LF}^{\mathrm{y}}$} & \multicolumn{4}{|c|}{$\mathrm{TQ}^{\mathrm{x}}$} \\
\hline & $\mathrm{EC}_{\mathrm{w}} 1.5$ & $\mathrm{EC}_{\mathrm{w}} 15$ & $\mathrm{EC}_{\mathrm{w}} 30$ & $\mathrm{EC}_{\mathrm{w}} 45$ & $\overline{\mathrm{EC}_{\mathrm{w}} 1.5}$ & $\mathrm{EC}_{\mathrm{w}} 15$ & $\mathrm{EC}_{\mathrm{w}} 30$ & $\mathrm{EC}_{\mathrm{w}} 45$ \\
\hline OKC1302 & $9.0 \mathrm{a}^{\mathrm{w}}$ & $7.8 \mathrm{a}$ & $5.2 \mathrm{a}$ & $2.0 \mathrm{~b}$ & $8.5 \mathrm{ab}$ & $7.7 \mathrm{a}$ & $5.3 \mathrm{a}$ & $2.0 \mathrm{~b}$ \\
\hline Latitude 36 & $9.0 \mathrm{a}$ & $6.8 \mathrm{~b}$ & $3.8 \mathrm{c}$ & $1.0 \mathrm{~d}$ & $8.8 \mathrm{a}$ & $6.8 \mathrm{~b}$ & $3.8 \mathrm{c}$ & $1.0 \mathrm{c}$ \\
\hline NorthBridge & $9.0 \mathrm{a}$ & $7.0 \mathrm{~b}$ & $4.2 \mathrm{c}$ & $1.7 \mathrm{bc}$ & $8.0 \mathrm{~cd}$ & $7.0 \mathrm{~b}$ & $4.2 \mathrm{bc}$ & $1.7 \mathrm{~b}$ \\
\hline Tifway & $9.0 \mathrm{a}$ & $6.7 \mathrm{~b}$ & $4.8 \mathrm{ab}$ & $2.7 \mathrm{a}$ & $8.2 \mathrm{bc}$ & $6.2 \mathrm{~d}$ & $4.8 \mathrm{a}$ & $2.7 \mathrm{a}$ \\
\hline Celebration & $9.0 \mathrm{a}$ & $7.0 \mathrm{~b}$ & $4.2 \mathrm{c}$ & $2.0 \mathrm{~b}$ & $8.0 \mathrm{~cd}$ & $6.7 \mathrm{bc}$ & $4.2 \mathrm{bc}$ & $2.0 \mathrm{~b}$ \\
\hline TifSport & $9.0 \mathrm{a}$ & $6.2 \mathrm{c}$ & $4.3 \mathrm{bc}$ & $1.5 \mathrm{c}$ & $7.7 \mathrm{~d}$ & $6.0 \mathrm{~d}$ & $4.2 \mathrm{bc}$ & $1.5 \mathrm{bc}$ \\
\hline Midlawn & $9.0 \mathrm{a}$ & $6.7 \mathrm{~b}$ & $2.7 \mathrm{~d}$ & $1.0 \mathrm{~d}$ & $8.0 \mathrm{~cd}$ & $6.3 \mathrm{~cd}$ & $2.3 \mathrm{~d}$ & $1.0 \mathrm{c}$ \\
\hline
\end{tabular}
salinity level increased. Before beginning the salinity treatments, TQ of all the bermudagrass entries ranged from 7.7 to 8.8 (Table 1). Results demonstrated differences among entries $(P=0.05)$ at $\mathrm{EC}=1.5 \mathrm{dS} \cdot \mathrm{m}^{-1}$, where 'Latitude 36 ' had better TQ than all other

Table 1. Effect of four salinity treatments on LF and TQ of seven bermudagrass. ${ }^{\mathrm{z}}$

${ }^{\mathrm{z}}$ Data were collected for $\mathrm{EC}_{\mathrm{w}} 1.5$ on day 0 , for $\mathrm{EC}_{\mathrm{w}} 15$ on day 10 , for $\mathrm{EC}_{\mathrm{w}} 30$ on day 20 , and $\mathrm{EC}_{\mathrm{w}} 45$ on day 30 of the experiments. $\mathrm{After}$ collecting the $\mathrm{EC}_{\mathrm{w}} 1.5$ data on day 0 , the salt concentration was increased by $5 \mathrm{dS} \cdot \mathrm{m}^{-1}$ daily until the $15 \mathrm{dS} \cdot \mathrm{m}^{-1}$ salinity level was reached and was held at $15 \mathrm{dS} \cdot \mathrm{m}^{-1}$ for $1 \mathrm{week}$. On day 10 , all data were collected for all entries for the $\mathrm{EC}_{\mathrm{w}} 15$ treatment level. This process was repeated for both the 30 and $45 \mathrm{dS} \cdot \mathrm{m}^{-1}$ treatment levels $(\mathrm{Marcum}$ and Pessarakli, 2006). In addition to the salinity treatment pots, a set of control pots was maintained at $1.5 \mathrm{dS} \cdot \mathrm{m}^{-1}$ throughout the study period.

${ }^{\mathrm{y}} \mathrm{LF}=$ leaf firing, rated on the scale of 1 to 9 , where $1=$ total leaf firing and $9=$ no leaf firing.

${ }^{\mathrm{x}} \mathrm{TQ}=$ turf quality, rated on the scale of 1 to 9 , where $1=$ dead or dormant turf, $6=$ acceptable turf, and $9=$ excellent turf.

${ }^{\mathrm{w}}$ Means accompanied by the same lowercase letter in the same column are not significantly different at the $P=0.05$ level (n $=6$ ). 
entries except OKC1302. When exposed to $15 \mathrm{dS} \cdot \mathrm{m}^{-1}$, all the entries declined in TQ, but TQ was acceptable and ranged from 6.0 to 7.7. OKC1302 outperformed all others at 15 $\mathrm{dS} \cdot \mathrm{m}^{-1}$. Turf quality of all entries dropped below acceptable levels thereafter. Turf quality was highest in OKC1302 and 'Tifway' at $30 \mathrm{dS} \cdot \mathrm{m}^{-1}$. At $45 \mathrm{dS} \cdot \mathrm{m}^{-1}$, 'Latitude $36^{\prime}$ ' and 'Midlawn' had lower TQ compared with OKC1302, 'Tifway', and 'Celebration', but no difference was found when 'Latitude 36' and 'Midlawn' were compared with 'TifSport'. Overall, means separation results of TQ were very similar to LF. OKC1302 had high TQ at 15 and $30 \mathrm{dS} \cdot \mathrm{m}^{-1}$, whereas 'Tifway' out performed all others at $45 \mathrm{dS} \cdot \mathrm{m}^{-1}$.

GreenSeeker $^{T M}$ normalized difference vegetation index. The NDVI readings as determined by the GreenSeeker ${ }^{\mathrm{TM}}$ handheld sensor under the various salinity treatments are presented in Table 2. Before salt was added to the treatment tank, differences among entries were detected, where 'Latitude
36' had higher GSNDVI than all other entries except OKC1302. At $15 \mathrm{dS} \cdot \mathrm{m}^{-1}$, the GSNDVI of OKC1302 was greater than 'Celebration', 'TifSport', and 'Midlawn', but was not different from 'Latitude 36', 'Tifway', or 'NorthBridge'. Interestingly, the bermudagrass entry values for GSNDVI slightly increased as the salinity dose increased from 1.5 to $15 \mathrm{dS} \cdot \mathrm{m}^{-1}$. However, the GSNDVI declined when comparing the performance of the control treatment with the $15 \mathrm{dS} \cdot \mathrm{m}^{-1}$ salinity treatment $(P=0.001)$ (Table 3$)$. The GSNDVI of all entries declined substantially as the salinity level was increased to $30 \mathrm{dS} \cdot \mathrm{m}^{-1}$ where 'Tifway' and OKC1302 exhibited the highest GSNDVI (Table 2). At $45 \mathrm{dS} \cdot \mathrm{m}^{-1}$, the GSNDVI values of all entries continued to decline and all fell below 0.300 .

FieldScout ${ }^{\circledR}$ normalized difference vegetation index. The FSNDVI values as determined by the FieldScout ${ }^{\circledR}$ CM 1000 NDVI meter declined as salinity levels increased (Table 2). Before the initiation of the salinity treatments, 'Latitude 36' obtained the highest FSNDVI value. As the salinity increased to $15 \mathrm{dS} \cdot \mathrm{m}^{-1}, \mathrm{FSNDVI}$ was higher in OKC1302 when compared with other entries with the exceptions of 'Latitude 36' and 'NorthBridge'. At $30 \mathrm{dS} \cdot \mathrm{m}^{-1}$, FSNDVI declined for all entries and was highest in 'Tifway' and $\mathrm{OKC} 1302$ and lowest in 'Midlawn'. 'Tifway' had the highest FSNDVI value at $45 \mathrm{dS} \cdot \mathrm{m}^{-1}$, but all entries continued to decline to less than 0.450. Compared with the control, the FSNDVI at the $15 \mathrm{dS} \cdot \mathrm{m}^{-1}$ salinity treatment FSNDVI of each entry declined significantly when compared with the control treatment $(P=0.001)$ (Table 3$)$ and continued to decline as salinity level increased (Table 2).

Dark green color index. The DGCI as determined by the FieldScout ${ }^{\circledR}$ GreenIndex + Turf App ranged from 0.706 to 0.829 for all entries at the beginning of the study (Table 4). Before the salinity treatment, 'Celebration' had higher DGCI than other entries with the

Table 2. Effect of four salinity treatments on the normalized difference vegetation index (NDVI) ${ }^{\mathrm{z}}$ derived from two handheld instruments.

\begin{tabular}{|c|c|c|c|c|c|c|c|c|}
\hline \multirow[b]{3}{*}{ Entry } & \multicolumn{8}{|c|}{ NDVI } \\
\hline & \multicolumn{4}{|c|}{ GSNDVI $^{\mathrm{y}}$} & \multicolumn{4}{|c|}{ FSNDVI $^{\mathrm{x}}$} \\
\hline & $\mathrm{EC}_{\mathrm{w}} 1.5$ & $\mathrm{EC}_{\mathrm{w}} 15$ & $\mathrm{EC}_{\mathrm{w}} 30$ & $\mathrm{EC}_{\mathrm{w}} 45$ & $\mathrm{EC}_{\mathrm{w}} 1.5$ & $\mathrm{EC}_{\mathrm{w}} 15$ & $\mathrm{EC}_{\mathrm{w}} 30$ & $\mathrm{EC}_{\mathrm{w}} 45$ \\
\hline$\overline{\mathrm{OKC}} 1302$ & $0.747 \mathrm{ab}^{\mathrm{w}}$ & $0.810 \mathrm{a}$ & $0.495 \mathrm{a}$ & $0.217 \mathrm{bc}$ & $0.713 \mathrm{~b}$ & $0.695 \mathrm{a}$ & $0.598 \mathrm{a}$ & $0.397 \mathrm{~b}$ \\
\hline Latitude 36 & $0.765 \mathrm{a}$ & $0.802 \mathrm{ab}$ & $0.417 b$ & $0.153 \mathrm{e}$ & $0.738 a$ & $0.692 \mathrm{ab}$ & $0.537 \mathrm{~b}$ & $0.327 \mathrm{de}$ \\
\hline NorthBridge & $0.725 \mathrm{c}$ & $0.800 \mathrm{ab}$ & $0.435 \mathrm{~b}$ & $0.182 \mathrm{de}$ & $0.709 \mathrm{~b}$ & $0.682 \mathrm{ab}$ & $0.562 \mathrm{~b}$ & $0.342 \mathrm{~cd}$ \\
\hline Tifway & $0.732 \mathrm{bc}$ & $0.802 \mathrm{ab}$ & $0.517 \mathrm{a}$ & $0.280 \mathrm{a}$ & $0.716 \mathrm{~b}$ & $0.690 \mathrm{ab}$ & $0.613 \mathrm{a}$ & $0.437 \mathrm{a}$ \\
\hline Celebration & $0.737 \mathrm{~b}$ & $0.783 \mathrm{bc}$ & $0.413 b$ & $0.245 \mathrm{~b}$ & $0.714 b$ & $0.675 \mathrm{bc}$ & $0.545 \mathrm{~b}$ & $0.393 \mathrm{~b}$ \\
\hline TifSport & $0.723 \mathrm{c}$ & $0.760 \mathrm{~d}$ & $0.428 \mathrm{~b}$ & $0.192 \mathrm{~cd}$ & $0.714 b$ & $0.663 \mathrm{c}$ & $0.548 \mathrm{~b}$ & $0.373 \mathrm{bc}$ \\
\hline Midlawn & $0.735 \mathrm{~b}$ & $0.767 \mathrm{~cd}$ & $0.260 \mathrm{c}$ & $0.110 \mathrm{f}$ & $0.714 \mathrm{~b}$ & $0.658 \mathrm{c}$ & $0.450 \mathrm{c}$ & $0.293 \mathrm{e}$ \\
\hline
\end{tabular}

${ }^{\mathrm{z}}$ Data were collected for $\mathrm{EC}_{\mathrm{w}} 1.5$ on day 0 , for $\mathrm{EC}_{\mathrm{w}} 15$ on day 10 , for $\mathrm{EC}_{\mathrm{w}} 30$ on day 20 , and $\mathrm{EC}_{\mathrm{w}} 45$ on day 30 of the experiments. After collecting the $\mathrm{EC}_{\mathrm{w}} 1.5$ data on day 0 , the salt concentration was increased by $5 \mathrm{dS} \cdot \mathrm{m}^{-1}$ daily until the $15 \mathrm{dS} \cdot \mathrm{m}^{-1}$ salinity level was reached and was held at $15 \mathrm{dS} \cdot \mathrm{m}^{-1}$ for $1 \mathrm{week}$. On day 10 , all data were collected for all entries for the $\mathrm{EC}_{\mathrm{w}} 15$ treatment level. This process was repeated for both the 30 and $45 \mathrm{dS} \cdot \mathrm{m}^{-1}$ treatment levels $(\mathrm{Marcum}$ and Pessarakli, 2006). In addition to the salinity treatment pots, a set of control pots was maintained at $1.5 \mathrm{dS} \cdot \mathrm{m}^{-1}$ throughout the study period.

${ }^{\mathrm{y}}$ GSNDVI $=$ NDVI reading determined by the GreenSeeker ${ }^{\mathrm{TM}}$ handheld sensor.

${ }^{\mathrm{x}}$ FSNDVI $=$ NDVI reading determined by the FieldScout ${ }^{\circledR}$ CM 1000 NDVI meter.

${ }^{\mathrm{w}}$ Means accompanied by the same lowercase letter in the same column are not significantly different at the $P=0.05$ level $(\mathrm{n}=6)$.

Table 3. LF, TQ, normalized difference vegetation index (NDVI), DGCI, and VR for seven bermudagrass under nonsalinity control and salinity treatment of 15 $\mathrm{dS} \cdot \mathrm{m}^{-1}$.

\begin{tabular}{|c|c|c|c|c|c|c|c|c|}
\hline Entry & $\mathrm{TRT}^{\mathrm{z}}$ & Salinity level (EC dS.m $\left.{ }^{-1}\right)$ & $\mathrm{LF}^{\mathrm{y}}$ & $\mathrm{TQ}^{\mathrm{x}}$ & FSNDVI $^{\mathrm{w}}$ & GSNDVI $^{\mathrm{v}}$ & $\mathrm{DGCI}^{\mathrm{u}}$ & $\mathrm{VR}^{\mathrm{t}}$ \\
\hline Celebration & Control & 1.5 & 9.0 & 9.0 & 0.753 & 0.858 & 0.783 & 8.37 \\
\hline Celebration & Salinity & 15 & $7.0 * *$ & $6.7 * * *$ & $0.675 * * *$ & $0.783 * * *$ & $0.721 * * *$ & $8.02^{\mathrm{NS}}$ \\
\hline Latitude 36 & Control & 1.5 & 9.0 & 9.0 & 0.763 & 0.868 & 0.714 & 7.72 \\
\hline Latitude 36 & Salinity & 15 & $6.8 * * *$ & $6.8 * * *$ & $0.692 * * *$ & $0.802 * * *$ & $0.711^{\mathrm{NS}}$ & $7.68^{\mathrm{NS}}$ \\
\hline Midlawn & Control & 1.5 & 9.0 & 8.3 & 0.752 & 0.853 & 0.639 & 7.03 \\
\hline Midlawn & Salinity & 15 & $6.7 * * *$ & $6.3 * * *$ & $0.658 * * *$ & $0.767 * * *$ & $0.661^{\mathrm{NS}}$ & $7.12^{\mathrm{NS}}$ \\
\hline NorthBridge & Control & 1.5 & 9.0 & 9.0 & 0.757 & 0.857 & 0.697 & 7.57 \\
\hline NorthBridge & Salinity & 15 & $7.0 * * *$ & $7.0 * * *$ & $0.682 * * *$ & $0.800 * * *$ & $0.716^{\mathrm{NS}}$ & $7.73^{\mathrm{NS}}$ \\
\hline OKC1302 & Control & 1.5 & 9.0 & 9.0 & 0.770 & 0.860 & 0.759 & 8.13 \\
\hline OKC1302 & Salinity & 15 & $7.8 * * *$ & $7.7 * * *$ & $0.695 * * *$ & $0.810 * * *$ & $0.737^{\mathrm{NS}}$ & $8.12^{\mathrm{NS}}$ \\
\hline TifSport & Control & 1.5 & 9.0 & 8.2 & 0.747 & 0.835 & 0.717 & 7.77 \\
\hline TifSport & Salinity & 15 & $6.2 * * *$ & $6.0 * * *$ & $0.663 * * *$ & $0.760 * * *$ & $0.729^{\mathrm{NS}}$ & $7.90^{\mathrm{NS}}$ \\
\hline Tifway & Control & 1.5 & 9.0 & 8.8 & 0.755 & 0.848 & 0.723 & 7.80 \\
\hline Tifway & Salinity & 15 & $6.7 * * *$ & $6.2 * * *$ & $0.690 * * *$ & $0.802 * * *$ & $0.783 *$ & $8.37 * * *$ \\
\hline
\end{tabular}

${ }^{\mathrm{z}} \mathrm{TRT}=$ treatment, includes control and salinity treatment collected at day 10 of the study. After collecting the 1.5 EC data from all pots on day 0 , the salt concentration for the EC 15 salinity level was increased by $5 \mathrm{dS} \cdot \mathrm{m}^{-1}$ daily until the $15 \mathrm{dS} \cdot \mathrm{m}^{-1}$ salinity level was reached and was held at $15 \mathrm{dS} \cdot \mathrm{m}^{-1}$ for 1 week. In addition to the salinity treatment pots, a set of control pots was maintained at $1.5 \mathrm{dS} \cdot \mathrm{m}^{-1}$ throughout the study period. On day 10 , all data were collected for all entries for both treatment levels (Marcum and Pessarakli, 2006).

${ }^{y_{L F}}=$ leaf firing, rated on the scale of 1 to 9 , where $1=$ total leaf firing and $9=$ no leaf firing.

${ }^{\mathrm{x}} \mathrm{TQ}=$ turf quality, rated on the scale of 1 to 9 , where $1=$ dead or dormant turf, $6=$ acceptable turf, and $9=$ excellent turf.

${ }^{\mathrm{w}} \mathrm{FSNDVI}=$ NDVI reading determined by the FieldScout ${ }^{\circledR}$ CM 1000 NDVI meter.

${ }^{\mathrm{v}}$ GSNDVI = NDVI reading determined by the GreenSeeker ${ }^{\mathrm{TM}}$ handheld sensor.

${ }^{\mathrm{u}} \mathrm{DGCI}=$ dark green color index determined by the FieldScout ${ }^{\circledR}$ GreenIndex + Turf App.

${ }^{\mathrm{t}} \mathrm{VR}=$ visual rating determined by the FieldScout ${ }^{\circledR}$ GreenIndex + Turf App.

NS $*, * *, * * *$ Not significant or significantly different from the control $\left(1.5 \mathrm{dS} \cdot \mathrm{m}^{-1}\right)$ at $P \leq 0.05,0.01$, or 0.001 , respectively, within entry and column by least significant difference. 
exceptions of OKC1302 and 'Tifway'. The DGCI was lowest in 'Midlawn', which was primarily due to its natural lighter green leaf color (National Turfgrass Evaluation Program, 2012). At $15 \mathrm{dS} \cdot \mathrm{m}^{-1}$, the DGCI was higher in 'Tifway' than all other entries with the exception of OKC1302. All entries declined significantly after the salinity level reached $30 \mathrm{dS} \cdot \mathrm{m}^{-1}$. At this level, 'Tifway' again showed a higher DGCI value than all other entries with the exception of OKC1302. At $45 \mathrm{dS} \cdot \mathrm{m}^{-1}$, the DGCI continued to decline for all entries and was highest in 'Tifway', with the exception of 'Celebration'. At the highest salinity stress level, the DGCI ranged from 0.212 to 0.313 .

Visual rating. Because the smartphone application calculated the VR based on data collected to calculate DGCI, the results were similar for both parameters (Table 4). At 15 $\mathrm{dS} \cdot \mathrm{m}^{-1}$, the lowest VR was detected in 'Midlawn' at 7.1. The average VR ranged from 3.9 to 5.9 at $30 \mathrm{dS} \cdot \mathrm{m}^{-1}$ where 'Tifway' was higher than all other entries with the exception of OKC1302. At $45 \mathrm{dS} \cdot \mathrm{m}^{-1}$, the VR was highest in 'Tifway' and 'Celebration' and lowest in 'Midlawn' and ranged from 3.0 to 3.9.

Digital image analysis. Before the salinity treatments, the DIA showed that 'Latitude 36 ' had higher live green coverage than all other entries (Table 5) due to its dense growth habit. The DIA showed a slight decline in live green coverage in all entries at $15 \mathrm{dS} \cdot \mathrm{m}^{-1}$ when compared with the decline at 30 and 45 $\mathrm{dS} \cdot \mathrm{m}^{-1}$. OKC1302 had higher live green coverage as measured by DIA than all other entries except 'Tifway' at $30 \mathrm{dS} \cdot \mathrm{m}^{-1}$. At 45 $\mathrm{dS} \cdot \mathrm{m}^{-1}$, 'Tifway' had higher live green coverage as measured by DIA than all other entries except 'Celebration'. All entries had significant linear, quadratic, and cubic trends, with the exception of 'Midlawn', which indicated that 'Midlawn' declined more quickly than all other entries. At the highest salinity level, DIA indicated that the live green coverage ranged from 3.08 ('Midlawn') to $19.83 \%$ ('Celebration').

Shoot weights. For all entries, the relative shoot dry weight (SW/SW control) declined linearly with increasing salinity levels with $r \geq 0.88$ (Table 6). Regression analysis showed that the SW25 and SW50 relative (to control) shoot growth reduction ranged from 11.5 to 12.3 and 22.9 to $24.5 \mathrm{dS} \cdot \mathrm{m}^{-1}$, respectively. Tifway needed a relatively higher predicted salinity level than all other entries to reach SW25 and SW50. The predicted salinity level in descending order for SW25 was 'Tifway' > 'Midlawn' > 'NorthBridge' $=$ 'Celebration' $>$ OKC1302 = 'TifSport' = 'Latitude 36'; and for SW50 was 'Tifway' > 'Midlawn' > 'NorthBridge' > 'Celebration' $>$ OKC1302 = 'TifSport' = 'Latitude 36'.

Correlation. All the TQ factors, including LF, TQ, FSNDVI, GSNDVI, DGCI, VR, and DIA, were highly positively correlated with one another $(r>0.9, P<0.0001$, Table 7), which indicated their mutual usefulness as salinity tolerance indicators.
Among the seven parameters, TQ and LF both had the highest correlation coefficient with the others and ranked as the best criterion of turfgrass evaluation under salinity stress. Shoot dry weight, as a physiological factor, was similar, but less correlated, to the other parameters.

Recovery. Recovery is not a direct way to evaluate salinity tolerance; however, the faster the grass can recover the better vigor the grass has. The live green cover ranged from $2.35 \%$ to $25.87 \% 2$ weeks after recovery (Table 8 ). A linear and cubic trend was detected in OKC1302, 'Latitude 36', 'NorthBridge', and 'Tifway', which demonstrated why they had better recovery between 2 and 4 weeks after beginning the recovery period. At week 8, 'NorthBridge' and OKC1302 obtained live green cover of $60.08 \%$ and $53.72 \%$, respectively, whereas 'TifSport' and 'Midlawn' had live green cover of only $25.63 \%$ and $29.86 \%$, respectively.

Table 4. Effect of four salinity treatments on DGCI and VR of seven bermudagrass as measured by the FieldScout ${ }^{\circledR}$ GreenIndex+ Turf App.

\begin{tabular}{|c|c|c|c|c|c|c|c|c|}
\hline \multirow[b]{3}{*}{ Entry } & \multicolumn{8}{|c|}{ Reading by the FieldScout ${ }^{\circledR}$ GreenIndex + Turf App } \\
\hline & \multicolumn{4}{|c|}{$\mathrm{DGCI}^{\mathrm{z}}$} & \multicolumn{4}{|c|}{$\mathrm{VR}^{\mathrm{y}}$} \\
\hline & $\mathrm{EC}_{\mathrm{w}} 1.5$ & $\mathrm{EC}_{\mathrm{w}} 15$ & $\mathrm{EC}_{\mathrm{w}} 30$ & $\mathrm{EC}_{\mathrm{w}} 45$ & $\mathrm{EC}_{\mathrm{w}} 1.5$ & $\mathrm{EC}_{\mathrm{w}} 15$ & $\mathrm{EC}_{\mathrm{w}} 30$ & $\mathrm{EC}_{\mathrm{w}} 45$ \\
\hline$\overline{\mathrm{OKC}} 1302$ & $0.795 \mathrm{ab}^{\mathrm{x}}$ & $0.737 \mathrm{ab}$ & $0.493 \mathrm{ab}$ & $0.278 \mathrm{bc}$ & $8.5 \mathrm{ab}$ & $8.1 \mathrm{ab}$ & $5.6 \mathrm{ab}$ & $3.6 \mathrm{~b}$ \\
\hline Latitude 36 & $0.752 \mathrm{bc}$ & $0.711 \mathrm{~b}$ & $0.403 \mathrm{c}$ & $0.238 \mathrm{de}$ & $8.1 \mathrm{bc}$ & $7.7 \mathrm{~d}$ & $4.8 \mathrm{~d}$ & $3.2 \mathrm{~cd}$ \\
\hline NorthBridge & $0.722 \mathrm{c}$ & $0.716 \mathrm{~b}$ & $0.417 \mathrm{c}$ & $0.252 \mathrm{~cd}$ & $7.8 \mathrm{~cd}$ & $7.7 \mathrm{~cd}$ & $4.9 \mathrm{~cd}$ & $3.4 \mathrm{bc}$ \\
\hline Tifway & $0.794 \mathrm{ab}$ & $0.783 \mathrm{a}$ & $0.522 \mathrm{a}$ & $0.313 \mathrm{a}$ & $8.5 \mathrm{ab}$ & $8.4 \mathrm{a}$ & $5.9 \mathrm{a}$ & $3.9 \mathrm{a}$ \\
\hline Celebration & $0.829 \mathrm{a}$ & $0.721 \mathrm{~b}$ & 0.46 & 0.30 & $8.8 \mathrm{a}$ & $8.0 \mathrm{bc}$ & $5.4 \mathrm{bc}$ & $3.9 \mathrm{a}$ \\
\hline TifSport & $0.775 \mathrm{~b}$ & $0.729 \mathrm{~b}$ & $0.408 \mathrm{c}$ & $0.262 \mathrm{~cd}$ & $8.3 \mathrm{~b}$ & $7.9 \mathrm{bcd}$ & $4.9 \mathrm{~d}$ & $3.5 \mathrm{bc}$ \\
\hline Midlawn & $0.706 \mathrm{~d}$ & $0.661 \mathrm{c}$ & $0.314 \mathrm{~d}$ & $0.212 \mathrm{e}$ & $7.6 \mathrm{~d}$ & $7.1 \mathrm{e}$ & $3.9 \mathrm{e}$ & $3.0 \mathrm{~d}$ \\
\hline
\end{tabular}

${ }^{\mathrm{z}} \mathrm{DGCI}=$ dark green color index determined by the FieldScout ${ }^{\circledR}$ GreenIndex + Turf App.

${ }^{\mathrm{y}} \mathrm{VR}=$ visual rating determined by the FieldScout ${ }^{\circledR}$ GreenIndex + Turf App.

${ }^{\mathrm{x}}$ Means accompanied by the same lowercase letter in the same column are not significantly different at the $P=0.05$ level $(\mathrm{n}=6)$.

Table 5. Effect of four salinity treatments and trend analysis on live green cover of seven bermudagrass assessed through digital image analysis (DIA).

\begin{tabular}{llcccc}
\hline & \multicolumn{5}{c}{ Live green cover $(\%)^{\mathrm{z}}$} \\
\cline { 2 - 5 } Entry & $\mathrm{EC}_{\mathrm{w}} 1.5$ & $\mathrm{EC}_{\mathrm{w}} 15$ & $\mathrm{EC}_{\mathrm{w}} 30$ & $\mathrm{EC}_{\mathrm{w}} 45$ & Significance \\
\hline OKC1302 & $96.84 \mathrm{~b}^{\mathrm{y}}$ & $95.52 \mathrm{a}$ & $59.24 \mathrm{a}$ & $15.71 \mathrm{bc}$ & $\mathrm{L}^{* *} \mathrm{Q}^{* *} \mathrm{C}^{* *}$ \\
Latitude 36 & $99.20 \mathrm{a}$ & $93.61 \mathrm{~b}$ & $42.46 \mathrm{~cd}$ & $4.82 \mathrm{~d}$ & $\mathrm{~L}^{* *} \mathrm{Q}^{* *} \mathrm{C}^{* *}$ \\
NorthBridge & $95.65 \mathrm{bc}$ & $93.26 \mathrm{bc}$ & $47.14 \mathrm{bc}$ & $9.41 \mathrm{~cd}$ & $\mathrm{~L}^{* *} \mathrm{Q}^{* *} \mathrm{C}^{* *}$ \\
Tifway & $94.79 \mathrm{c}$ & $91.27 \mathrm{~cd}$ & $55.88 \mathrm{ab}$ & $24.73 \mathrm{a}$ & $\mathrm{L}^{* *} \mathrm{Q}^{* *} \mathrm{C}^{* *}$ \\
Celebration & $96.84 \mathrm{~b}$ & $89.21 \mathrm{de}$ & $49.82 \mathrm{bc}$ & $19.83 \mathrm{ab}$ & $\mathrm{L}^{* *} \mathrm{Q}^{*} \mathrm{C}^{* *}$ \\
TifSport & $90.90 \mathrm{~d}$ & $83.68 \mathrm{f}$ & $34.64 \mathrm{~d}$ & $5.79 \mathrm{~d}$ & $\mathrm{~L}^{* *} \mathrm{Q}^{* *} \mathrm{C}^{* *}$ \\
Midlawn & $97.10 \mathrm{~b}$ & $86.97 \mathrm{e}$ & $23.50 \mathrm{e}$ & $3.08 \mathrm{~d}$ & $\mathrm{~L}^{* *} \mathrm{C}^{* *}$ \\
\hline
\end{tabular}

${ }^{\mathrm{Z}}$ Live green coverage percent is the DIA as a percentage determined by SigmaScan software. The least significant difference grouping was presented after arcsin transformation.

${ }^{y}$ Means accompanied by the same lowercase letter in the same column are not significantly different at the $P=0.05$ level $(\mathrm{n}=6)$.

*, **Significant linear (L), quadratic (Q), or cubic (C) trend at $P=0.05$ and 0.01 , respectively, by Fisher's $\mathrm{F}$ test.

Table 6. Predicted salinity level for $25 \%$ shoot growth reduction (SW25) and 50\% shoot growth reduction (SW50) of seven bermudagrass.

\begin{tabular}{lcccc}
\hline & Regression of relative shoot growth & & \multicolumn{2}{c}{ Predicted salinity level $\left(\mathrm{dS} \cdot \mathrm{m}^{-1}\right)$} \\
\cline { 3 - 5 } Entry & under different stress & $r^{2}$ & $\mathrm{SW} 25$ & $\mathrm{SW} 50$ \\
\hline OKC1302 & $y=-0.0254 x+1.1647$ & 0.9611 & 11.5 & 22.9 \\
Latitude36 & $y=-0.0245 x+1.1231$ & 0.94003 & 11.5 & 22.9 \\
NorthBridge & $y=-0.0221 x+1.0297$ & 0.89899 & 11.6 & 23.3 \\
Tifway & $y=-0.0228 x+1.1181$ & 0.95326 & 12.3 & 24.5 \\
Celebration & $y=-0.0276 x+1.282$ & 0.88997 & 11.6 & 23.2 \\
TifSport & $y=-0.0211 x+0.9666$ & 0.92162 & 11.5 & 22.9 \\
Midlawn & $y=-0.021 x+0.994$ & 0.97509 & 11.8 & 23.7 \\
\hline
\end{tabular}


All the entries had acceptable TQ and only a minor decline in percentage cover when exposed to $15 \mathrm{dS} \cdot \mathrm{m}^{-1}$. Severe declines were found when the treatment reached $30 \mathrm{dS} \cdot \mathrm{m}^{-1}$. Although relatively brief in duration, these findings demonstrate that the bermudagrass tested in this study may be effectively managed in moderately low salinity levels $\left(\leq 15 \mathrm{dS} \cdot \mathrm{m}^{-1}\right)$. Lee et al. (2004a, 2004b) demonstrated that 'Tifway' has better shoot growth and total biomass growth than 'TifSport' when exposed to different salinity stress treatments, which aligns with the results of this study. Relative slow recovery rate was also detected in 'TifSport' when compared with 'Tifway'.

Among all the parameters, LF had a better correlation with other parameters; LF has been considered an important criterion to evaluate salinity tolerance in turfgrass (Uddin et al., 2011). We recommend that turf bermudagrass breeders use LF in selecting for salinity tolerance in segregating populations and subsequently developing salinitytolerant cultivars.

Among the sensor-based parameters, DIA showed better accuracy than GSNDVI and DGCI/VR. This is likely because DIA was conducted with a black bucket with artificial

Table 7. Pearson correlation coefficient for LF, TQ, normalized difference vegetation index (NDVI), DGCI, VR, SW, and DIA in the clonal bermudagrass trial.

\begin{tabular}{lcllllllc}
\hline Parameter & LF $^{z}$ & TQ $^{\mathrm{y}}$ & FSNDVI $^{\mathrm{x}}$ & GSNDVI $^{\mathrm{w}}$ & DGCI $^{\mathrm{v}}$ & VR $^{\mathrm{u}}$ & SW $^{\mathrm{t}}$ & DIA $^{\mathrm{s}}$ \\
\hline LF & 1 & $0.971^{* * *}$ & $0.946^{* * *}$ & $0.936^{* * *}$ & $0.908^{* * *}$ & $0.907^{* * *}$ & $0.719^{* * *}$ & $0.954^{* * *}$ \\
TQ & & 1 & $0.950^{* * *}$ & $0.939^{* * *}$ & $0.918^{* * *}$ & $0.917^{* * *}$ & $0.705^{* * *}$ & $0.965^{* * *}$ \\
FSNDVI & & & 1 & $0.961^{* * *}$ & $0.920^{* * *}$ & $0.92^{* * *}$ & $0.669^{* * *}$ & $0.953^{* * *}$ \\
GSNDVI & & & & 1 & $0.907^{* * *}$ & $0.907^{* * *}$ & $0.735^{* * *}$ & $0.950^{* * *}$ \\
DGCI & & & & & 1 & $0.999^{* * *}$ & $0.596^{* * *}$ & $0.934^{* * *}$ \\
VR & & & & & & 1 & $0.593^{* * *}$ & $0.934^{* * *}$ \\
SW & & & & & & & 1 & $0.712^{* * *}$ \\
DIA & & & & & & & & 1 \\
\hline
\end{tabular}

${ }^{\mathrm{z}} \mathrm{LF}=$ leaf firing, rated on the scale of 1 to 9 , where $1=$ total leaf firing and $9=$ no leaf firing.

${ }^{\mathrm{y}} \mathrm{TQ}=$ turf quality, rated on the scale of 1 to 9 , where $1=$ dead or dormant turf, $6=$ acceptable turf, and $9=$ excellent turf.

${ }^{\mathrm{x}}$ FSNDVI $=$ NDVI reading determined by the FieldScout ${ }^{\circledR}$ CM 1000 NDVI meter.

${ }^{\mathrm{w}}$ GSNDVI $=$ NDVI reading determined by the GreenSeeker ${ }^{\mathrm{TM}}$ handheld sensor.

${ }^{\mathrm{v}}$ DGCI $=$ dark green color index determined by the FieldScout ${ }^{\circledR}$ GreenIndex + Turf App.

${ }^{\mathrm{u}} \mathrm{VR}=$ visual rating determined by the FieldScout ${ }^{\circledR}$ GreenIndex + Turf App.

${ }^{\mathrm{t}} \mathrm{SW}=$ shoot dry weight.

${ }^{\mathrm{s} D I A}=$ digital image analysis determined by SigmaScan software.

${ }^{* * * *}$ Indicates significant of correlations at $P=0.001$.

Table 8. Recovery results and trend analysis on live green cover of seven bermudagrass assessed through digital image analysis (DIA) for an 8-week period.

\begin{tabular}{lccccc}
\hline & \multicolumn{5}{c}{ Live green cover $(\%)^{\mathrm{z}}$} \\
\cline { 2 - 5 } Entry & 0 week & 2 weeks & 4 weeks & 8 weeks & Significance \\
\hline OKC1302 & $15.71 \mathrm{bc}^{\mathrm{y}}$ & $18.578 \mathrm{a}$ & $51.05 \mathrm{a}$ & $53.72 \mathrm{a}$ & $\mathrm{L}^{* * \mathrm{C}^{*}}$ \\
Latitude36 & $4.82 \mathrm{~d}$ & $2.352 \mathrm{c}$ & $33.54 \mathrm{ab}$ & $43.75 \mathrm{ab}$ & $\mathrm{L}^{* *} \mathrm{C}^{*}$ \\
NorthBridge & $9.41 \mathrm{~cd}$ & $15.272 \mathrm{abc}$ & $49.53 \mathrm{a}$ & $60.08 \mathrm{a}$ & $\mathrm{L}^{* *} \mathrm{C}^{*}$ \\
Tifway & $24.73 \mathrm{a}$ & $25.865 \mathrm{a}$ & $55.16 \mathrm{a}$ & $53.05 \mathrm{ab}$ & $\mathrm{L}^{* *} \mathrm{C}^{* *}$ \\
Celebration & $19.83 \mathrm{ab}$ & $17.996 \mathrm{ab}$ & $38.76 \mathrm{ab}$ & $38.53 \mathrm{ab}$ & $\mathrm{L}^{* *}$ \\
TifSport & $5.79 \mathrm{~d}$ & $4.721 \mathrm{bc}$ & $16.08 \mathrm{~b}$ & $25.63 \mathrm{~b}$ & $\mathrm{~L}^{* *}$ \\
Midlawn & $3.08 \mathrm{~d}$ & $13.234 \mathrm{abc}$ & $30.19 \mathrm{ab}$ & $29.86 \mathrm{~b}$ & $\mathrm{~L}^{* *}$ \\
\hline
\end{tabular}

${ }^{\mathrm{z}}$ Live green coverage is the DIA as a percentage determined by SigmaScan software, least significant difference grouping was presented after arcsin transformation.

${ }^{\mathrm{y}}$ Means accompanied by the same lowercase letter in the same column are not significantly different at the $P=0.05$ level $(\mathrm{n}=6)$.

${ }^{*},{ }^{* *}$ Significant linear $(\mathrm{L})$, quadratic $(\mathrm{Q})$, or cubic $(\mathrm{C})$ trend at $P=0.05$ and 0.01 , respectively, by Fisher's $\mathrm{F}$ test.

Table 9. Rank of salinity tolerance of seven bermudagrass entries.

\begin{tabular}{lcc}
\hline Entry & Times in top statistical group & Times in bottom statistical group \\
\hline Tifway & 21 & 3 \\
OKC1302 & 19 & 1 \\
Celebration & 6 & 3 \\
Latitude 36 & 7 & 6 \\
NorthBridge & 3 & 5 \\
TifSport & 2 & 11 \\
Midlawn & 1 & 23 \\
\hline
\end{tabular}

${ }^{\mathrm{z}}$ Number of times of 28 total that the entry's mean ranked in the top or bottom statistical ranking group (according to Fisher's least significant difference at $P=0.05$ ) for the categories with a significant $\mathrm{F}$ test. These include leaf firing, turf quality, normalized difference vegetation index (NDVI) determined by the GreenSeeker ${ }^{\mathrm{TM}}$ handheld sensor, NDVI determined by the FieldScout ${ }^{\circledR}$ CM 1000 NDVI meter, dark green color index, and visual rating, and digital image analysis determined by the FieldScout ${ }^{\circledR}$ GreenIndex + Turf App.

lighting to ensure each photo was taken under the same lighting conditions. We collected the GSNDVI, DGCI, and VR under natural light conditions in the greenhouse, according to the manufacturer's recommendations. Even though the FieldScout ${ }^{\circledR}$ GreenIndex+ Turf App adjusted for white balance, the DGCI results could be improved by controlling the light conditions with a similar black bucket that contains artificial lighting to control conditions.

Unlike the findings concerning all other parameters, no significant treatment differences were observed in the VR as measured by the FieldScout ${ }^{\circledR}$ GreenIndex+ Turf App at $15 \mathrm{dS} \cdot \mathrm{m}^{-1}$. This finding suggests that this device/app is less accurate in assessing VR than other salinity tolerance assessment tools. This may be because VR is calculated by the green color index, and TQ is not only related to the color but also to a combination of density, texture, uniformity, and environmental stress.

Differences were detected in GSNDVI among entries, even for the control. Increases in GSNDVI were also found at $15 \mathrm{dS} \cdot \mathrm{m}^{-1}$. It is speculated that the stability of the GreenSeeker ${ }^{\mathrm{TM}}$ handheld sensor might be affected by other environmental or mechanical factors, such as the percentage of the battery power level. At a low battery level, less light may be reflected back to the sensor due to less red and IR light being emitted from the sensor to the canopy. Considering the variations created by the environment, we did not compare data among different days; we did, however, compare the control with the salinity treatment of each entry each day. We speculate that the GreenSeeker ${ }^{\mathrm{TM}}$ handheld sensor and the FieldScout ${ }^{\circledR}$ GreenIndex+ Turf App might be sensitive and easily affected by environmental factors, especially light conditions. The accuracy of GSNDVI might also be limited by the size of the measuring area. The small canopy area of the greenhouse pots in this study may have contributed to higher correlations for FSNDVI than for GSNDVI; FSNDVI is also very simple to use and less time consuming. This indicates that FSNDVI is more suitable for measuring salinity tolerance in turf greenhouse research.

Results from this study showed that the salinity levels leading to SW25 and SW50 had a very narrow range. Compared with the other parameters, SW showed similar results, but with some exceptions. Grasses with high relative shoot growth generally had less LF and better TQ. However, there were exceptions. At $30 \mathrm{dS} \cdot \mathrm{m}^{-1}$, 'Midlawn' had a relative shoot growth at $27.16 \%$ but had high LF (2.7), whereas 'Tifway' had a lower relative shoot growth at $25.88 \%$ than 'Midlawn', but had less LF (5.2). These issues show that there are complicated mechanisms present in salinity tolerance of bermudagrass and that other factors that limit plant growth can be difficult to detect (Lee et al., 2004b).

Compared with the linear function used in this study and prior studies (Marcum and Pessarakli, 2006), a nonlinear function may 
also be appropriate when comparing the relative shoot growth of bermudagrass (Table 6). Therefore, it is recommended to use more salinity treatment levels with a smaller incremental scale to better discern the response of relative bermudagrass shoot growth.

\section{Literature Cited}

Ashraf, M. and A. Waheed. 1990. Screening of local/exotic accessions of lentil (Lens culinaris Medic.) for salt tolerance at two growth stages. Plant Soil 128:167-176.

Basyouni, R. 2014. Use of nondestructive optical sensors in assessing nitrogen status in six popular greenhouse plants. Okla. State Univ., Stillwater, MS Thesis.

Basyouni, R. and B. Dunn. 2013. Use of optical sensors to monitor plant nitrogen status in horticultural plants (HLA 6719-4). Okla. Coop. Ext. Serv., Stillwater, OK. 30 July 2016. <http:// pods.dasnr.okstate.edu/docushare/dsweb/Get/ Document-9045/HLA-6719web.pdf>.

Bell, G.E., D.L. Martin, K. Koh, and H.R. Han. 2009. Comparison of turfgrass visual quality ratings with ratings determined using a handheld optical sensor. HortTechnology 19:309316.

Bell, G.E. and X. Xiong. 2008. The history, role, and potential of optical sensing for practical turf management, p. 641-658. In: M. Pessarakli (ed.). Handbook of turfgrass management and physiology. CRC Press, Boca Raton, FL.

Carillo, P., M.G. Annunziata, G. Pontecorvo, A. Fuggi, and P. Woodrow. 2011. Salinity stress and salt tolerance. In: A. Shanker and B. Venkateswarlu (eds.). Abiotic stress in plants: Mechanisms and adaptations. InTech. doi: $10.5772 / 22331$.

Crain, J., I. Ortiz-Monasterio, and B. Raun. 2012. Evaluation of a reduced cost active NDVI sensor for crop nutrient management. J. Sens., doi: $10.1155 / 2012 / 582028$.

Deering, D.W., J.W. Rouse, Jr., R.H. Haas, and J.A. Schell. 1975. Measuring "forage production" of grazing units from Landsat MSS data. Proc. Tenth Intl. Symp. on Remote Sensing of Environ., Univ. Michigan, Ann Arbor. p. 1169-1178.

Guimaraes, F.V.A., C.F. Lacerda, E.C. Marques, C.E.B. Abreu, B.F. Aquino, J.T. Prisco, and E. Gomes-Filho. 2012. Supplemental $\mathrm{Ca}^{2+}$ does not improve growth but it affects nutrient uptake in NaCl-stressed cowpea plants. Braz. J. Plant Physiol. 24:9-18.

Hanna, W., P. Raymer, and B. Schwartz. 2013. Warm-season grasses: Biology and breeding, $\mathrm{p}$. 543-590. In: J.C. Stier, B.P. Horgan, and S.A. Bonos (eds.). Turfgrass: Biology, use, and management. Agron. Monogr. 56. ASA and SSSA, Madison, WI.

Jacoby, B. 1999. Mechanism involved in salt tolerance of plants, p. 97-124. In: M. Pessarakli (ed.). Handbook of plant and crop stress. Marcel Dekker Inc., New York.

Karcher, D.E. and M.D. Richardson. 2003. Quantifying turfgrass color using digital image analysis. Crop Sci. 43:943-951.

Koch, M.J. and S.A. Bonos. 2011. Salinity tolerance of cool-season turfgrass cultivars under field conditions. Appl. Turfgrass Sci. 8(1):0-0.

Lee, G., R.N. Carrow, and R.R. Duncan. 2004a. Salinity tolerance of selected seashore paspalums and bermudagrass: Root and verdure responses and criteria. HortScience 39:11431147.

Lee, G., R.R. Duncan, and R.N. Carrow. 2004b. Salinity tolerance of seashore paspalum ecotypes: Shoot growth response and criteria. HortScience 39:1138-1142.

Leinauer, B., D.M. VanLeeuwen, M. Serena, M. Schiavon, and E. Sevostianova. 2014. Digital image analysis and spectral reflectance to determine turfgrass quality. Agron. J. 106 (5):1787-1794.

Marcum, K.B. 1999. Salinity tolerance mechanisms of grasses in the subfamily chlorideae. Crop Sci. 31:1153-1160.

Marcum, K.B. 2008. Relative salinity tolerance of turfgrass species and cultivars, p. 389-406. In: M. Pessaraki (ed.). Handbook of turfgrass management and physiology. CRC Press, New York, NY.

Marcum, K.B. and C.L. Murdoch. 1994. Salinity tolerance mechanisms of six $\mathrm{C}_{4}$ turfgrasses. J. Amer. Soc. Hort. Sci. 119:779-784.

Marcum, K.B. and M. Pessarakli. 2006. Salinity tolerance and salt gland excretion efficiency of bermudagrass turf cultivars. Crop Sci. 46:2571-2574.

Marcum, K.B., M. Pessarakli, and D. Kopec. 2005. Relative salinity tolerance of 21 turf-type desert saltgrasses compared to bermudagrass. HortScience 40:827-829.
Morris, K.N. 2007. A guide to NTEP turfgrass ratings. National Turfgrass Evaluation Program, Beltsville, MD. 30 July 2016. <http:// www.ntep.org/reports/ratings.htm>.

Munns, R. and M. Tester. 2008. Mechanisms of salinity tolerance. Annu. Rev. Plant Biol. 59:651-681.

Munshaw, G.C., X. Zhang, and E.H. Ervin. 2004. Effect of salinity on bermudagrass cold hardiness. HortScience 39:420-423.

National Turfgrass Evaluation Program. 2012. The 2007 national bermudagrass test: Genetic color ratings of bermudagrass cultivars. National Turfgrass Evaluation Program, Beltsville, MD.

National Turfgrass Evaluation Program. 2013. The 2013 national bermudagrass test: Entries and sponsors. National Turfgrass Evaluation Program, Beltsville, MD

Richardson, M.D. 2001. Quantifying turfgrass cover using digital image analysis. Crop Sci. 41:1884-1888.

Sevostianova, E., B. Leinauer, R. Sallenave, D. Karcher, and B. Maier. 2011. Soil salinity and quality of sprinkler and drip irrigated cool-season turfgrass. Agron. J. 103:15031513.

Spectrum Technologies, Inc. 2013. Product manual, Item no. 2953. 30 July 2016. <http://www. specmeters.com/assets/1/22/2953CM1000NDVI1. pdf $>$.

Spectrum Technologies, Inc. 2014. Product manual, Item no. 2910TA, 2910T. <http://www. specmeters.com/assets/1/22/2910TA_2910T_ GreenIndex_Turf1.pdf $>$.

Taliaferro, C., F.M. Rouquette, Jr., and P. Mislevy. 2004. Bermudagrass and stargrass, p. 417475. In: L.E. Moser, B.L. Burson, and L.E. Sollenberger (eds.). Warm-season (C4) grasses. Agron. Monogr. 45. ASA and SSSA, Madison, WI.

Uddin, M.K., A.S. Juraimi, M.R. Isnail, M.R Ismail, R. Othman, and A.A. Rahim. 2011. Relative salinity tolerance of warm season turfgrass species. J. Environ. Biol. 32:309312.

U.S. Golf Association Green Section Staff. 2004. USGA recommendations for a method of putting green construction. U.S. Golf Assn., Far Hills, NJ. 30 July 2016. <http://hutchesonsand. com/site/wpcontent/uploads/2012/10/USGA_ Recommendations_For_a_Method_of_Putting Green_Construction.pdf $>$. 